\title{
Public Libraries and Community Information Services: An Experience in Blocks of Sundarban Region, South 24 Parganas
}

\author{
Arindam Sarkar \\ Department of Library and Information Science, Jadavpur University, Kolkata - 700032, \\ West Bengal, India; infoarindam83@gmail.com
}

\begin{abstract}
Public libraries are called people's university. The objective of this paper is to examine the relationship between public library and Community Information Services (CIS) in various blocks of Sundarban region, of South 24 Parganas district. Community Information Services is one through which a public library provides community information to members of the community it serves. This paper also discusses Community Library cum Information Centres (CLICs). Examining the librarians' as well as users' perspectives, an effort has been made to offer some suggestions.
\end{abstract}

Keywords: Community Information Service, Community Library cum Information Centres (CLICs), Public Libraries, West Bengal

\section{Introduction}

"Bad libraries build collections, Good libraries build services, Great libraries build communities."

- R. David Lankes

These words from the famous library professional R. David Lankes (ALA Ken Haycock award winner for promoting librarianship) emphasize the importance of libraries, especially the public library, in building a community. Out of 28 states and 7 union territories in India, only 20 states have enacted public library legislation (Ramaiah \& Sankara, 2010). Public libraries play the role of an essential academic and socio-cultural organization for the community. In West Bengal public libraries are part of the State Government in terms of administration and finances. Most of the in West Bengal population lives in rural regions. In this context, the public library can play an important role in the advancement of society through education and other community services. It can be effectively carried out with well-structured and planned library system and services. An important issue related to public libraries is community information service, the specific information which is mostly desired by a specific community. Community information refers to the types and range of information needed by the members of the community for their dayto-day problem solving. Library Association provided a comprehensive definition of Community Information Services: "Community Information Services are those, which assist individual and groups with daily problem solving and with participation in the democratic process. The services concentrate on the needs of those who do not have ready access to other sources of assistance on the most important problems that people have to face, problems to do with their homes, their jobs and their rights" (Library Association, 1980). The main object and interest of this study is to examine the present status of community information services provided by public libraries and how far it satisfied users of Sundarban regions, South 24 Parganas district, West Bengal, India.

\section{Objectives}

The objectives of the study are as follows:

1. To examine Community Information Services through public libraries and CLICs in the Blocks of Sudarban region, South 24 Parganas, 
2. To identify the challenges users face regarding Community Information Services from the public libraries,

3. To find out the availability of ICT infrastructure of selected libraries, and

4. To suggest measures for the improvement of Community Information Services in public libraries.

\section{Scope and Limitation}

According to website of Mass Education Extension and Library Services Department, Government of West Bengal, there are 180 public libraries in the five sub-divisions of South 24 Parganas. Out of 180 public libraries, twenty-six (26) public libraries and Eleven (11) CLICs were selected from blocks of Sundarban regions. In case of users 60 users were selected from different areas of that region. The present study was conducted in the selected public libraries.

\section{Methodology}

Survey method was employed for data collection and data were collected from librarians and users using questionnaires by physically visiting the libraries and in a few cases via telephonic conversation. The collected data were analyzed and tabulated keeping in view the objectives of the study.

\section{Data Analysis and Findings}

The selected public libraries for this study - Sub-division and block-wise are listed in the Table 1.

Table 1. List of selected libraries and CLICs from thirteen blocks of sundarban regions of south 24 Pages

\begin{tabular}{|c|l|c|}
\hline \multirow{1}{*}{ Block } & \multicolumn{1}{|c|}{ Library Name } & $\begin{array}{c}\text { Type of } \\
\text { Library }\end{array}$ \\
\hline Joynagar-I & Bandhab Library, Jaynagar I & TL \\
\cline { 2 - 3 } & $\begin{array}{l}\text { Baharu Shyamsundar Public } \\
\text { Library, Jaynagar I }\end{array}$ & TL \\
\cline { 2 - 3 } & $\begin{array}{l}\text { Jangalia Janagranthagar O } \\
\text { Tathyakendra }\end{array}$ & CLIC \\
\hline
\end{tabular}

\begin{tabular}{|c|c|c|}
\hline \multirow[t]{3}{*}{ Joynagar-II } & $\begin{array}{l}\text { Milan Sangha Pathagar, } \\
\text { Phutigoda, Joynagar II }\end{array}$ & $\mathrm{RL}$ \\
\hline & KalimataPathagar, Joynagar II & RL \\
\hline & $\begin{array}{l}\text { Nalgora Janagranthagar } \\
\text { Tathyakendra }\end{array}$ & CLIC \\
\hline \multirow[t]{3}{*}{ Kultali } & $\begin{array}{l}\text { Kachimara Netaji Library, } \\
\text { Kultali }\end{array}$ & $\mathrm{RL}$ \\
\hline & Jalaberia Rural Library & RL \\
\hline & $\begin{array}{l}\text { Kundakhali-Godabor } \\
\text { Janagranthagar }\end{array}$ & CLIC \\
\hline \multirow[t]{3}{*}{ Gosaba } & $\begin{array}{l}\text { Bali Palli Unnayan Pathagar, } \\
\text { Gosaba }\end{array}$ & RL \\
\hline & $\begin{array}{l}\text { Chhoto Mollakhali Public } \\
\text { Library, Gosaba }\end{array}$ & RL \\
\hline & $\begin{array}{l}\text { Sambhunaga Janagranthagar } \\
\text { O Tathyakendra }\end{array}$ & CLIC \\
\hline \multirow[t]{3}{*}{ Basanti } & Netaji Pathagar, Basanti & RL \\
\hline & $\begin{array}{l}\text { Sonakhali Tarun Tirtha } \\
\text { Pathagar, Basanti }\end{array}$ & RL \\
\hline & $\begin{array}{l}\text { Baratgarh Janagranthagar O } \\
\text { Tathyakendra }\end{array}$ & CLIC \\
\hline \multirow[t]{3}{*}{ Canning-I } & $\begin{array}{l}\text { Canning Public Library, } \\
\text { Canning I }\end{array}$ & $\mathrm{TL}$ \\
\hline & Taldi Netaji Pathagar, Canning I & RL \\
\hline & $\begin{array}{l}\text { Deuli II G.P. Janagranthagar } \\
\text { O Tathyakendra }\end{array}$ & CLIC \\
\hline \multirow[t]{3}{*}{ Canning-II } & $\begin{array}{l}\text { Matherdighi Udayan } \\
\text { Pathagar, Canning II }\end{array}$ & $\mathrm{RL}$ \\
\hline & $\begin{array}{l}\text { MallickkatiSadharanPathagar, } \\
\text { Canning II }\end{array}$ & RL \\
\hline & $\begin{array}{l}\text { Matla II Janagranthagar O } \\
\text { Tathyakendra }\end{array}$ & CLIC \\
\hline \multirow[t]{3}{*}{ Sagar } & $\begin{array}{l}\text { Sree Sree Ramkrishna } \\
\text { Sadharan Pathagar, sagar }\end{array}$ & $\mathrm{RL}$ \\
\hline & Sagar Town Libaray, Sagar & $\mathrm{TL}$ \\
\hline & $\begin{array}{l}\text { Gangasagar GP Jana } \\
\text { Granthagar O tathyakendra }\end{array}$ & CLIC \\
\hline \multirow[t]{2}{*}{$\begin{array}{l}\text { Pathar } \\
\text { Pratima }\end{array}$} & $\begin{array}{l}\text { Daksin Sundarban Sanhati } \\
\text { Sansad, Pathar Pratima }\end{array}$ & $\mathrm{RL}$ \\
\hline & $\begin{array}{l}\text { Paschim Surendra Nagar } \\
\text { Young Public Library, }\end{array}$ & $\mathrm{RL}$ \\
\hline
\end{tabular}




\begin{tabular}{|c|c|c|}
\hline \multirow[t]{3}{*}{ Namkhana } & $\begin{array}{l}\text { Narayanpur Sree Durga } \\
\text { Pathagar, Namkhana }\end{array}$ & $\mathrm{RL}$ \\
\hline & $\begin{array}{l}\text { Frezerganj Bijoli Club \& } \\
\text { Library, Namkhana }\end{array}$ & $\mathrm{RL}$ \\
\hline & $\begin{array}{l}\text { Shibrampur Community } \\
\text { Library/Information Cnt. }\end{array}$ & CLIC \\
\hline \multirow[t]{2}{*}{ Kakdwip } & $\begin{array}{l}\text { Vidhasagar Sadharan } \\
\text { Pathagar. Kakdwip }\end{array}$ & RL \\
\hline & Agradut Pathagar, Kakdwip & RL \\
\hline \multirow[t]{3}{*}{ Mathurapur-I } & $\begin{array}{l}\text { Vivekananda Seva Sangha } \\
\text { Library, Mathurapur I }\end{array}$ & RL \\
\hline & Anirban Pathagar & RL \\
\hline & $\begin{array}{l}\text { Lakshinarayanpur Dakhin } \\
\text { Jana granthagar O Thatya } \\
\text { kendra }\end{array}$ & CLIC \\
\hline \multirow[t]{3}{*}{ Mathurapur-II } & $\begin{array}{l}\text { Chakratirtha Sadharan } \\
\text { Pathagar, Raidighi }\end{array}$ & $\mathrm{RL}$ \\
\hline & $\begin{array}{l}\text { Dr. Usha Ranjan Memorial } \\
\text { Public Librar }\end{array}$ & $\mathrm{RL}$ \\
\hline & $\begin{array}{l}\text { Raidighi GP Janagranthagar O } \\
\text { Tathyakendra }\end{array}$ & CLIC \\
\hline
\end{tabular}

$\mathrm{TL}=$ Town Library, RL=Rural Library

The availability of various basic Community Information Services as per library records and librarians' statement in these public libraries and CLICs is shown in the Table 2.

Table 2. Availability of common type of community information services within selected libraries

\begin{tabular}{|l|c|}
\hline \multicolumn{1}{|c|}{ Types of CIS } & \multicolumn{1}{|c|}{$\begin{array}{c}\text { No. of Providing } \\
\text { Libraries } \\
\text { (Out of 37 Libraries) }\end{array}$} \\
\hline Agriculture \& related & 14 \\
\hline Fishing \& related & 4 \\
\hline Forestry \& related & 2 \\
\hline Education related & 7 \\
\hline Employment related & 6 \\
\hline Health Information & 9 \\
\hline Animal husbandry & 0 \\
\hline Govt. Program & 31 \\
\hline Financial assistance & 0 \\
\hline Local political News & 0 \\
\hline Legal aids & 0 \\
\hline
\end{tabular}

\begin{tabular}{|l|c|}
\hline Social Welfare & 4 \\
\hline Art and Culture & 10 \\
\hline Consumer Information & 14 \\
\hline
\end{tabular}

The Table 2 indicates that common types of CIS are provided only in a small number of public libraries. The situation in rural and primary unit libraries and CLICs is not satisfactory compared to town /Sub-division libraries.

Table 3 shows the positive and negative responses of users to the question "Can you fulfill your need from CIS"?

Table 3. Can the users fulfill their need from Community Information Services provided by libraries/CLICs?

\begin{tabular}{|l|c|c|}
\hline & Say Yes & Say No \\
\hline Number of users & 11 & 49 \\
\hline Percentage of users & $18.33 \%$ & $81.67 \%$ \\
\hline
\end{tabular}

Table 3 reveals that only $18.33 \%$ of total users agreed that Community Information Services satisfied their needs and the remaining $81.67 \%$ indicated that their needs were not met.

Table 4 indicates users' perceptions about issues related to provision of Community Information Services through public libraries and CLICs.

Table 4. Users' perceptions regarding issues in community information services through public libraries and CLICs

\begin{tabular}{|c|l|c|c|c|}
\hline $\begin{array}{c}\text { SL. } \\
\text { No. }\end{array}$ & \multicolumn{1}{|c|}{ Perception } & Yes & $\begin{array}{c}\text { Not } \\
\text { Clear }\end{array}$ & No \\
\hline 1. & $\begin{array}{l}\text { Lack of Planning and } \\
\text { infrastructure }\end{array}$ & 29 & 22 & 9 \\
\hline 2. & $\begin{array}{l}\text { Lack of proper staff to } \\
\text { assist me }\end{array}$ & 39 & 10 & 11 \\
\hline 3. & $\begin{array}{l}\text { Lack of knowledge } \\
\text { of area profile among } \\
\text { library representatives }\end{array}$ & 31 & 7 & 22 \\
\hline 4. & $\begin{array}{l}\text { Attitude of authority and } \\
\text { librarian(s) not being } \\
\text { user friendly }\end{array}$ & 23 & 19 & 18 \\
\hline 5. & $\begin{array}{l}\text { Lack of proper } \\
\text { information resources / } \\
\text { collection base }\end{array}$ & 26 & 17 & 17 \\
\hline
\end{tabular}

Above table shows users' views about problems of Community Information Services reflected through responses to various questions. Table 5 it is seen that most of the users thought that there are problems. 
Table 5. Probable solutions for better and effective community information service (As suggested by users)

\begin{tabular}{|l|c|c|c|}
\hline \multicolumn{1}{|c|}{ Probable Solutions } & Yes & $\begin{array}{c}\text { Not } \\
\text { Clear }\end{array}$ & No \\
\hline $\begin{array}{l}\text { Identification of needs of } \\
\text { community }\end{array}$ & 47 & 6 & 7 \\
\hline Improve public relations & 43 & 15 & 2 \\
\hline Librarians should be user friendly & 46 & 14 & 0 \\
\hline $\begin{array}{l}\text { Information literacy and user } \\
\text { education }\end{array}$ & 27 & 19 & 14 \\
\hline $\begin{array}{l}\text { Collection and preservation of } \\
\text { indigenous knowledge }\end{array}$ & 39 & 15 & 6 \\
\hline $\begin{array}{l}\text { Computer awareness programmes } \\
\text { and training about Internet }\end{array}$ & 24 & 21 & 15 \\
\hline Preparation of area profile & 37 & 9 & 14 \\
\hline
\end{tabular}

According to Table 5 (probable solution), 47 respondents suggested that there must be a provision of community need identification, 46 users thought that librarian should be user friendly and 43 users suggested that library should have a way to improve public relations. 27 users suggested that library must provide user education and information literacy programmes for better achievement. 39 users suggested building indigenous knowledge collection and preservation to assist the community. 24 people suggested that implementation of Computer awareness programmes and training programmes about Internet is essential and 37 users mentioned that there must be an option for area profile preparation.

\section{Findings of the Study}

The study reveals that:

- Most of the libraries and CLICs are not prepared at all for providing community information services,

- There are no proper plans and programmes regarding preparation of area profile, preparation of collection base, user education, and infrastructure development,

- Staff attitude towards users is discouraging,

- Except town libraries other libraries lack computers and Internet connection. Some library staff are also not familiar with digital environment, and

- CLICs are present according to official paper but do not satisfy community needs.

\section{Conclusion}

This study is very much relevant to the present situation when the number of users of public libraries is decreasing day by day. The development of public library services in West Bengal is not satisfactory, especially when compared with the situation in many other countries of the world. A CIS-based public library service is an effective way of meeting information needs of urban and rural communities. It is a challenge for librarians of public libraries to work in this context. Public library may act as a Community Information Centre and collect information to meet the information need of the people of the community, who are unaware of the sources of the information, the process of collecting and applying the same. Librarians must play an active role in providing appropriate guidance and services to the members of the community. They must interact with communities to find their real needs. Also Governments must have some initiatives towards CLICs for community information service, especially for the rural community.

\section{References}

Gilbert, K. (2015). A survey of user's satisfaction with public library services in Mubi, Adamawa State. IOSR Journal of Humanities and Social Science, 20(8), 52-57, Retrieved from www.iosrjournals.org/iosr-jhss/papers/Vol20-issue8/ Version-3/H020835257.pdf

Library Association (1980). Community Information: What libraries can Do: A Consultative Document. London: The Library Association. Working Party on Community Information, The University of Michigan; 135p. ISBN: 0853658722, 9780853658726. https://books.google.co.in/ books/about/Community_Information.html?id=MN7gAAAAMAAJ\&redir_esc $=y$.

Majumder, K.P. (2016). Community information services through public libraries and information centres: An experience in West Bengal, India. Qualitative and Quantitative Methods in Libraries, 5:797-804, Retrieved from www. qqml.net/papers/...2016.../544QQML_Journal_2016_ Majumder_797-804.pdf

Ramaiah, L.S. and Sankara Reddy, M. (2010). Position and status of public libraries in India: A critical study. In: L.S. Ramaiah et al. (Eds.), National conference on public libraries in the knowledge societies, Vijayawada: APLA: p. 9-19. 